\title{
Prognostic value of androgen receptor in triple negative breast cancer: A meta-analysis
}

\author{
Changjun Wang ${ }^{1, *}$, Bo Pan ${ }^{1, *}$, Hanjiang Zhu ${ }^{2}$, Yidong Zhou ${ }^{1}$, Feng Mao ${ }^{1}$, Yan Lin ${ }^{1}$, \\ Qianqian $X \mathbf{u}^{1}$, Qiang Sun ${ }^{1}$ \\ ${ }^{1}$ Department of Breast Surgery, Peking Union Medical College Hospital, Beijing, China \\ ${ }^{2}$ Department of Dermatology, University of California, San Francisco, CA, USA \\ *These authors have contributed equally to this work \\ Correspondence to: Qiang Sun, email: sunqiangpumch@sina.com \\ Keywords: androgen receptor, breast cancer, triple negative breast cancer, prognostic value, meta-analysis \\ Received: April 12, $2016 \quad$ Accepted: June 03, $2016 \quad$ Published: June 21, 2016
}

\section{ABSTRACT}

Background: Androgen receptor (AR) is a promising therapeutic target for breast cancer. However, its prognostic value remains controversial in triple negative breast cancer (TNBC). Here we present a meta-analysis to investigate the correlation between AR expression and TNBC prognosis.

Results: Thirteen relevant studies with 2826 TNBC patients were included. AR positive rate was $\mathbf{2 4 . 4 \%}$. AR+ patients tended to have lower tumor grade ( $p<$ $0.001)$, but more lymph node metastases $(p<0.01)$. AR positivity was associated with prolonged disease free survival (HR 0.809, 95\% CI $=0.659-0.995, p<0.05$ ), but had no significant impact on overall survival (HR 1.270, 95\% CI $=0.904-1.782, p$ $=0.168)$. No difference in survival existed between subgroups using different AR or estrogen receptor cutoff values.

Materials and methods: Literature search was performed in Pubmed, Embase and Cochrane Central Register of Controlled Trials databases to identify relevant articles on AR and TNBC prognosis. Fixed- and random-effect meta-analyses were conducted based on the heterogeneity of included studies. Heterogeneity and impacts of covariates were further evaluated by subgroup analyses and meta-regression.

Conclusion: AR positivity is associated with lower risk of disease recurrence in TNBC. Further clinical studies are warranted to clarify its prognostic role on TNBC recurrence and survival.

\section{INTRODUCTION}

Triple-negative breast cancer (TNBC) comprises $10-17 \%$ of breast cancer [1]. Since TNBC was insensitive to endocrine or target therapy, it was considered to have the poorest prognosis among different molecular subtypes [2,3]. Numerous studies have been carried out on sub-classifying TNBC to find valuable prognostic and therapeutic markers. Lehmann et al. demonstrated that TNBC is highly heterogeneous and consists of various subgroups, such as basal-like, immune-modulatory, mesenchymal, mesenchymal stem-like, and luminal androgen receptor (LAR) subtypes [4], among which the LAR subgroup characterized with high AR expression and poor prognosis [5].
$\mathrm{AR}$ is expressed in $60-70 \%$ of breast cancer and approximate $0-53 \%$ of TNBC [6]. As a novel target for endocrine therapy, its therapeutic effect largely depends on estrogen receptor (ER) status. For ER+/AR+ breast cancer cell lines, AR activation had anti-proliferative effect [7-9]; in contrast, it induced pro-proliferative effect for ER-/AR+ cell lines. $[4,7,8,10]$. Therefore, the antagonism of AR against ER may provide a new perspective for endocrine therapy.

Several clinical studies were conducted to evaluate AR prognostic value in breast cancer. It has been validated that AR positivity is associated with prolonged survival in ER+ breast cancer.[11-13]. However, the correlation between AR expression and prognosis remains elusive in TNBC. Study by Tang et al. suggested that absence of 
AR expression in TNBC served as a high-risk factor for both disease recurrence and death [14]. Similarly, several studies of (neo-) adjuvant chemotherapy reported AR positivity as an independent predictor for pathological complete response [15] and improved TNBC survival [16]. On the contrary, another cohort study revealed that AR+ TNBC had worse survival [17].

Hence, we conducted a meta-analysis including 13 studies to evaluate the prognostic value of AR in TNBC. This is the first meta-analysis to investigate the impact of AR expression on TNBC survival.

\section{RESULTS}

Among 4226 potentially relevant citations, 67 full-text articles were retrieved for detailed evaluation. Ultimately, 13 studies with 2826 patients were included in the meta-analysis (Figure 1) [13-25]. Both disease-free survival (DFS) and overall survival (OS) were available for 11 studies, while the other two studies had only DFS [22] or OS [23] reported. Supplementary Table S1 showed the quality assessment of included studies.

Table 1 summarizes the main characteristics of included studies. One study $(7.7 \%)$ included only postmenopausal women, the other 12 studies $(92.3 \%)$ included both pre- and post-menopausal women. ER and progesterone receptor (PR) cutoff values were reported in seven studies $(53.8 \%)$ : one study $(7.7 \%)$ used $0 \%$, two studies $(15.4 \%)$ used $1 \%$, and four studies (30.8\%) used 10\%. Twelve studies (92.3\%) used immunohistochemical (IHC) staining for AR assessment, the other one used Reverse-phase protein lysate microarray. The cutoff value for AR positivity was reported in $10(76.9 \%)$ of 12 studies: one study $(7.7 \%)$ used $0 \%$, three studies $(23.1 \%)$ used $1 \%$, one study $(7.7 \%)$ used $5 \%$, and four studies $(30.8 \%)$ used $10 \%$.

Table 2 showed the correlation between AR status and clinico-pathological parameters. Twelve studies (92.3\%) reported AR+ percentage. Among these twelve studies, AR expressed in 637 (24.4\%) of 2615 patients. AR expression was higher in post-menopausal women (post- vs. pre-menopausal $26.9 \%$ vs $13.4 \%, p<0.001$ ), grade 1-2 tumor (Grade 1-2 vs. 3, 40.8\% vs. 23.0\%, $p<$ 0.001 ) and patients with axillary LN metastases (LN+vs. LN-, $28.8 \%$ vs. $22.6 \%, p<0.01$ ). AR expression had no significant correlation with $\mathrm{T}$ stage, ductal or non-ductal cancer, lymphatic vascular invasion, surgical treatment, and adjuvant chemotherapy.

\section{Disease free survival}

Twelve $(92.3 \%)$ of the 13 studies reported hazard ratio (HR) of DFS, among which four studies were estimated by univariate survival analysis (log-rank test), eight studies by multivariate analysis (Cox proportional hazards model). There was no heterogeneity between included studies (Cochrane's Q $p=0.119$, I-square $=$

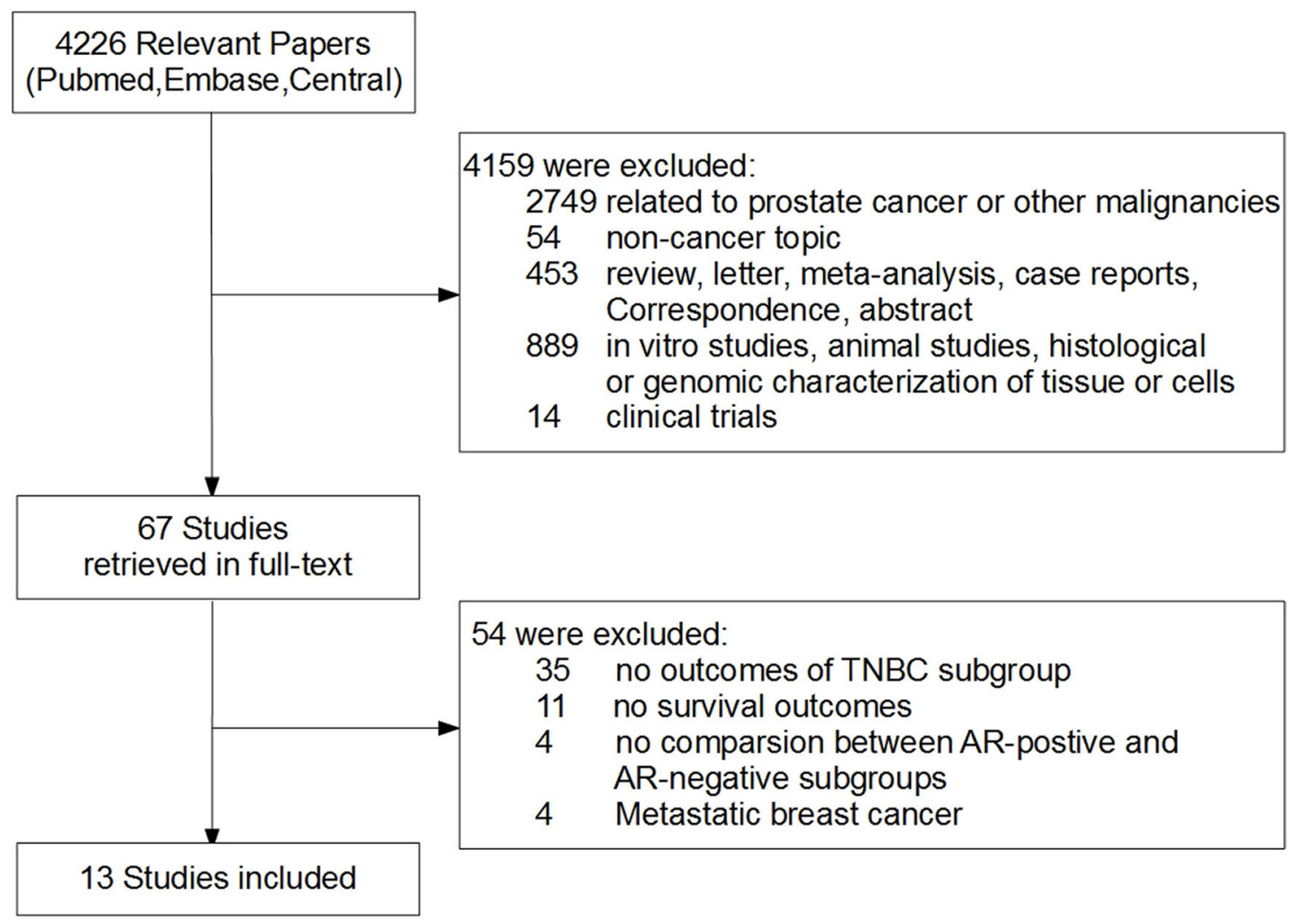

Figure 1: Flowchart of articles reviewed and included in meta-analysis. 
Table 1: Characteristics of studies included in meta-analysis

\begin{tabular}{|c|c|c|c|c|c|c|c|c|c|c|}
\hline \multirow{2}{*}{ Study } & \multirow{2}{*}{ Country } & \multirow{2}{*}{$\mathbf{N}$} & \multirow{2}{*}{ Patients } & \multirow{2}{*}{$\begin{array}{c}\text { Follow- } \\
\text { up } \\
\text { (m) }\end{array}$} & \multirow{2}{*}{$\begin{array}{c}\text { menopausal } \\
\text { status }\end{array}$} & \multirow{2}{*}{$\begin{array}{c}\text { Cutoff } \\
\text { for ER/ } \\
\text { PR(-) }\end{array}$} & \multirow{2}{*}{$\begin{array}{c}\text { AR } \\
\text { Antibody }\end{array}$} & \multicolumn{2}{|c|}{ Assessment of $\mathrm{AR}(+)$} & \multirow{2}{*}{$\begin{array}{c}\mathrm{AR}(+) \\
(\%)\end{array}$} \\
\hline & & & & & & & & Methods & Cutoff value & \\
\hline $\begin{array}{l}\text { Choi } 2015 \\
{[17]}\end{array}$ & $\begin{array}{l}\text { South } \\
\text { Korea }\end{array}$ & 492 & $\begin{array}{l}\text { Whole } \\
\text { cohort }\end{array}$ & $1-202$ & Pre-/Post- & $\begin{array}{l}\text { IHC } \\
(<1 \%)\end{array}$ & $\begin{array}{c}\text { ER179(2) } \\
\text { (Epitomics) }\end{array}$ & $\mathrm{IHC}$ & $\geq 1 \%$ & $87(17.7)$ \\
\hline $\begin{array}{l}\text { Doberstein } \\
2014 \text { [25] }\end{array}$ & Austria & 52 & $\begin{array}{l}\text { Whole } \\
\text { cohort }\end{array}$ & NR & Pre-/Post- & NR & $\begin{array}{c}\text { SP107 } \\
\text { (Ventana) }\end{array}$ & $\mathrm{IHC}$ & $\geq 10 \%$ & $21(40.4)$ \\
\hline $\begin{array}{l}\text { Gonzalez- } \\
\text { Angulo } \\
2009[24]\end{array}$ & $\begin{array}{l}\text { United } \\
\text { States }\end{array}$ & 97 & Subgroup & $\begin{array}{c}9.6- \\
110.4\end{array}$ & Pre-/Post- & $\begin{array}{c}\mathrm{IHC} \\
(<10 \%) / \\
\text { RPPA }\end{array}$ & $\begin{array}{l}\text { AR antibody } \\
\text { (Epitomics) }\end{array}$ & RPPA & $\begin{array}{c}\text { Log mean } \\
\text { centered } \\
\text { value } \geq 0.0852\end{array}$ & $16(16.5)$ \\
\hline $\begin{array}{l}\text { He } 2012 \\
{[23]}\end{array}$ & China & 287 & $\begin{array}{l}\text { Whole } \\
\text { cohort }\end{array}$ & $8-182$ & Pre-/Post- & NR & $\begin{array}{l}\text { AR antibody } \\
\text { (DAKO) }\end{array}$ & $\mathrm{IHC}$ & $\geq 5 \%$ & $74(25.8)$ \\
\hline $\begin{array}{l}\text { Hu } 2011 \\
{[22]}\end{array}$ & $\begin{array}{l}\text { United } \\
\text { States }\end{array}$ & 211 & Subgroup & $\begin{array}{c}\text { Median } \\
168\end{array}$ & Post- & NR & $\begin{array}{c}\text { AR441 } \\
\text { (DAKO) }\end{array}$ & $\mathrm{IHC}$ & $\geq 1 \%$ & NR \\
\hline $\begin{array}{l}\text { Loibl } 2011 \\
\text { [15] }\end{array}$ & German & 111 & Subgroup & $1.5-96.7$ & Pre-/Post- & $\begin{array}{c}\mathrm{IHC} \\
(<10 \%)\end{array}$ & $\begin{array}{c}\text { F39.4.1 } \\
\text { (BioGenex) }\end{array}$ & $\mathrm{IHC}$ & $\begin{array}{c}\text { Remmele } \\
\text { Score } 3\end{array}$ & $24(21.6)$ \\
\hline $\begin{array}{l}\text { Luo } 2010 \\
{[16]}\end{array}$ & China & 137 & $\begin{array}{l}\text { Whole } \\
\text { cohort }\end{array}$ & NR & Pre-/Post- & NR & NR & $\mathrm{IHC}$ & IHC score ${ }^{a}$ & $38(27.7)$ \\
\hline $\begin{array}{l}\text { McGhan } \\
2014 \text { [21] }\end{array}$ & $\begin{array}{l}\text { United } \\
\text { States }\end{array}$ & 94 & $\begin{array}{l}\text { Whole } \\
\text { cohort }\end{array}$ & $0-118.8$ & Pre-/Post- & NR & $\begin{array}{c}\text { AR441 } \\
(\mathrm{DAKO})\end{array}$ & $\mathrm{IHC}$ & $\geq 10 \%$ & $22(23.0)$ \\
\hline $\begin{array}{l}\text { Park } 2011 \\
{[13]}\end{array}$ & $\begin{array}{l}\text { South } \\
\text { Korea }\end{array}$ & 156 & Subgroup & $\begin{array}{c}\text { Mean } \\
72.7\end{array}$ & Pre-/Post- & $\begin{array}{c}\mathrm{IHC} \\
(<10 \%)\end{array}$ & $\begin{array}{l}\text { AR441 } \\
\text { (Thermo } \\
\text { scientific) }\end{array}$ & $\mathrm{IHC}$ & $\geq 10 \%$ & $21(13.5)$ \\
\hline $\begin{array}{l}\text { Pistelli } \\
2014 \text { [20] }\end{array}$ & Italy & 81 & $\begin{array}{l}\text { Whole } \\
\text { cohort }\end{array}$ & $2.5-95$ & Pre-/Post- & $\begin{array}{c}\mathrm{IHC} \\
(<10 \%)\end{array}$ & $\begin{array}{c}\text { F39.4.1 } \\
\text { (BioGenex) }\end{array}$ & $\mathrm{IHC}$ & $\geq 10 \%$ & $15(18.8)$ \\
\hline $\begin{array}{l}\text { Rakha } \\
2007 \text { [19] }\end{array}$ & $\begin{array}{l}\text { United } \\
\text { kingdom }\end{array}$ & 282 & Subgroup & $\begin{array}{l}\text { DFS } \\
1-206 \\
\text { OS } \\
1-206\end{array}$ & Pre-/Post- & $\begin{array}{l}\mathrm{IHC} \\
(0 \%)\end{array}$ & $\begin{array}{c}\text { F39.4.1 } \\
\text { (BioGenex) }\end{array}$ & IHC & $\geq 0 \%$ & $36(12.8)$ \\
\hline $\begin{array}{l}\text { Tang } 2012 \\
{[14]}\end{array}$ & China & 127 & $\begin{array}{l}\text { Whole } \\
\text { cohort }\end{array}$ & $\begin{array}{c}\text { DFS } \\
10-52 \\
\text { OS 10- } \\
52\end{array}$ & Pre-/Post- & NR & $\begin{array}{c}\text { AR441 } \\
(\mathrm{DAKO})\end{array}$ & IHC & $\geq 10 \%$ & $16(12.6)$ \\
\hline $\begin{array}{l}\text { Thike } \\
2014 \text { [18] }\end{array}$ & Singapore & 699 & $\begin{array}{l}\text { Whole } \\
\text { cohort }\end{array}$ & $1-213$ & Pre-/Post- & $\begin{array}{l}\mathrm{IHC} \\
(<1 \%)\end{array}$ & $\begin{array}{c}\text { AR27 } \\
\text { NCL-AR318 } \\
\text { (Novocastra) }\end{array}$ & IHC & $\geq 1 \%$ & $267(38.0)$ \\
\hline
\end{tabular}

AR: Androgen receptor; ASCO: American Society of Clinical Oncology; DFS: Disease free survival; ER: Estrogen receptor; FISH: Fluorescence in situ hybridization; IHC: Immunohistochemical staining; NR: Not reported; OS: overall survival; PR: Progesterone receptor; RPPA: Reverse-phase protein lysate microarray;

a Score according to the percentage of positive cells and staining intensity [16].

$33.9 \%$ ). AR expression in TNBC was associated with improved DFS (HR 0.809, 95\% CI $=0.659-0.995, p$ $<0.05$ ) (Figure 2). For subgroup using multi-variate analysis, the pooled result of AR associated DFS remained significant $(\mathrm{HR} 0.789,95 \% \mathrm{CI}=0.629-0.991$, $p<0.05)$.

For different AR cutoffs, neither low cutoff (0 or $1 \%$ ), nor high cutoff ( 5 or $10 \%$ ) subgroups revealed ARrelated benefit for DFS (HR 0.861, 95\% CI $=0.494-1.503$, $p=0.181$; HR 0.754, 95\% CI=0.531-1.072 $p=0.115$, respectively) (Figure 3, Supplementary Table S2). There was no statistical difference between different AR cutoffs $(p=0.654)$, study population (whole-cohort with TNBC
Vs. TNBC subgroup [ $p=0.693])$, ethnicity $(p=0.168)$ or ER cutoffs ( 0 or $1 \%$ vs. $10 \%, p=0.270$ ) (Supplementary Table S2).

\section{Overall survival}

Among 12 studies with OS data, five studies estimated HR by univariate survival analysis, seven studies by multivariate analysis. Heterogeneity existed among included studies (Cochrane's Q $p<0.01$, I-square $=58.9 \%$ ). By random-effect meta-analysis, AR positivity was not associated with any improvement in OS (HR $1.270,95 \% \mathrm{CI}=0.904-1.782, p=0.168)($ Figure 4$)$. 
Table 2: Correlation between androgen receptor expression and clinicopathological parameters in triple negative breast cancer patients

\begin{tabular}{|c|c|c|c|c|c|}
\hline & & AR- (\%) & $\mathrm{AR}+(\%)$ & OR (CI) & $p$ value \\
\hline \multirow[t]{3}{*}{$\begin{array}{l}\text { Menopausal } \\
\text { status }\end{array}$} & & & & $0.423(0.247-0.709)$ & $<0.001$ \\
\hline & Pre- & $174(86.6)$ & $27(13.4)$ & & \\
\hline & Post- & $174(73.1)$ & $64(26.9)$ & & \\
\hline \multirow[t]{3}{*}{ T stage } & & & & $0.846(0.667-1.070)$ & 0.153 \\
\hline & $\mathrm{T} 1$ & $438(75.0)$ & $146(25.0)$ & & \\
\hline & $\mathrm{T} 2-4$ & $774(71.7)$ & $305(28.3)$ & & \\
\hline \multirow[t]{3}{*}{ Pathology } & & & & $0.934(0.641-1.380)$ & 0.716 \\
\hline & Ductal & $973(72.9)$ & $362(27.1)$ & & \\
\hline & Non Ductal & $113(71.5)$ & $45(28.5)$ & & \\
\hline \multirow[t]{3}{*}{$\begin{array}{l}\text { Histological } \\
\text { grade }\end{array}$} & & & & $2.317(1.806-2.969)$ & $<0.001$ \\
\hline & Grade $1-2$ & $223(59.2)$ & $154(40.8)$ & & \\
\hline & Grade 3 & $\begin{array}{c}1047 \\
(77.0)\end{array}$ & $312(23.0)$ & & \\
\hline \multirow[t]{3}{*}{ LVI } & & & & $1.082(0.841-1.394)$ & 0.530 \\
\hline & No & $735(71.1)$ & $299(28.9)$ & & \\
\hline & Yes & $335(72.7)$ & $126(27.3)$ & & \\
\hline \multirow[t]{3}{*}{$\begin{array}{l}\text { Lymph-node } \\
\text { metastasis }\end{array}$} & & & & $0.723(0.578-0.904)$ & $<0.01$ \\
\hline & No & $558(77.4)$ & $163(22.6)$ & & \\
\hline & Yes & $790(71.2)$ & $319(28.8)$ & & \\
\hline \multirow[t]{3}{*}{$\begin{array}{l}\text { Surgical } \\
\text { treatment }\end{array}$} & & & & $1.567(0.919-2.748)$ & 0.085 \\
\hline & Mastectomy & $249(73.9)$ & $88(26.1)$ & & \\
\hline & Lumpectomy & $102(81.6)$ & $23(18.4)$ & & \\
\hline \multirow[t]{3}{*}{ Chemotherapy } & & & & $1.170(0.619-2.137)$ & 0.584 \\
\hline & No & $45(72.6)$ & $17(27.4)$ & & \\
\hline & Yes & $771(75.7)$ & $248(24.3)$ & & \\
\hline
\end{tabular}

AR: Androgen receptor; CI: Confidence interval LVI: Lymphovascular invasion; OR: Odds ratio;

For different AR cutoffs, neither low cutoff (0 or $1 \%$ ) nor high cutoff ( 5 or $10 \%$ ) subgroup revealed AR-related benefit for OS (HR $1.159,95 \% \mathrm{CI}=0.578$ $2.324 p=0.678$; HR 1.350, 95\% CI $=0.988-1.843 p=$ 0.059 , respectively) (Figure 5, Supplementary Table S3). There was no statistical significance between different AR cutoffs $(p=0.350)$, study population (whole cohort vs. subgroup of cohort, $p=0.791)$, ethnicity $(p=0.054)$, ER cutoffs ( 0 or $1 \%$ vs. $10 \%, p=0.654)$ or statistical analysis (univariate vs. multivariate, $p=$ 0.165) (Supplementary Table S3). Removal of one study with post-menopausal women only [22] had no significant impact on heterogeneity of meta-analysis or pooled result of OS (I-square 59.1\%, HR 1.195, 95\% CI $=0.821-1.740)($ Supplementary Table S3).

\section{Meta-regression}

Meta-regression was performed on outcome data. None of the covariates showed statistically significant effects on DFS or OS (Supplementary Table S4).

\section{Publication bias}

Funnel plots (Figure 6) for DFS and OS analyses were fairly symmetrical, and Begg's test revealed no 


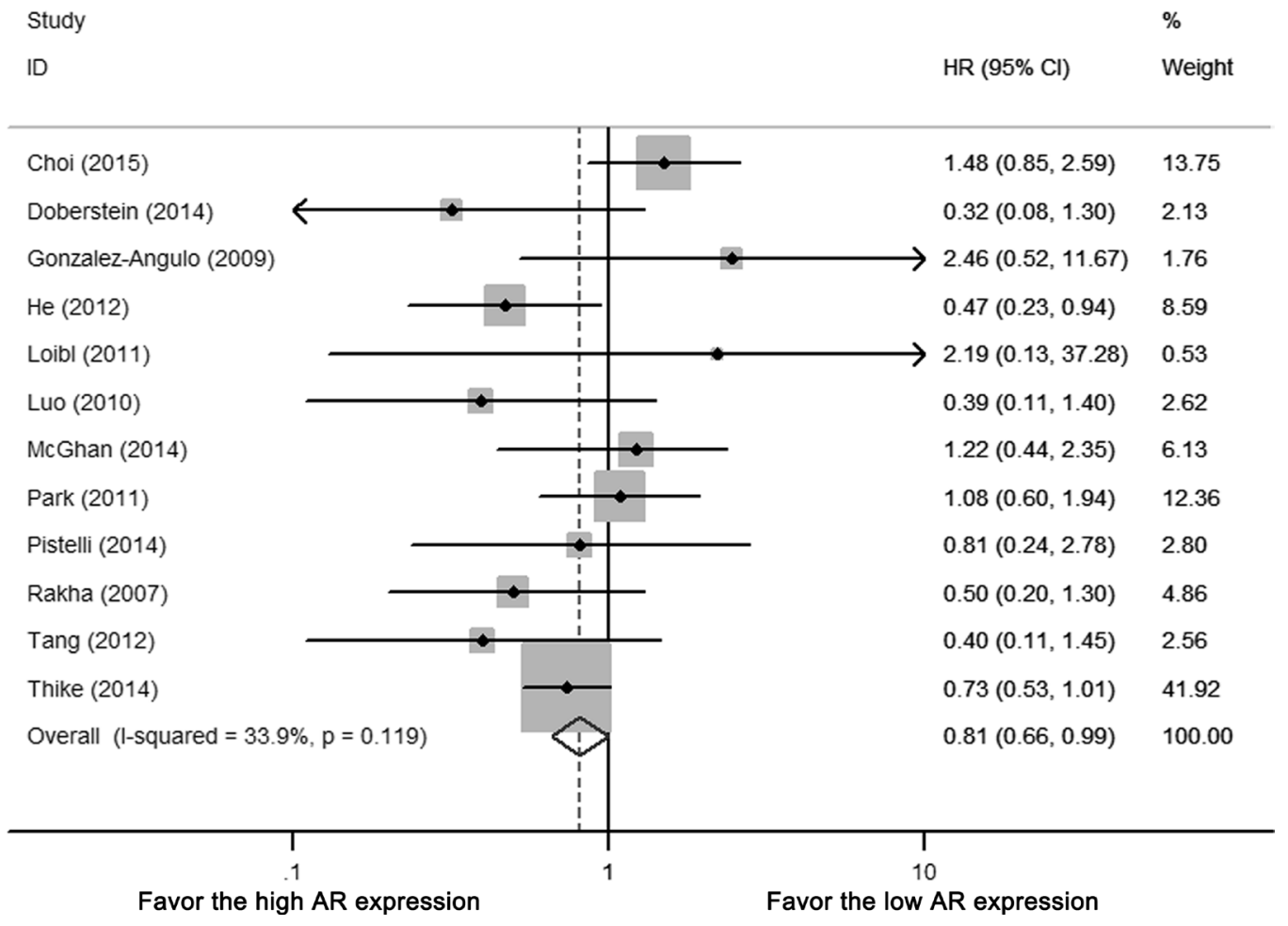

Figure 2: Forest plot of HR for DFS. Square indicate point estimate of each study. Size of square indicates relative contribution of each study. Solid horizontal line represents $95 \%$ CI of each study. Diamond indicates pooled studies.

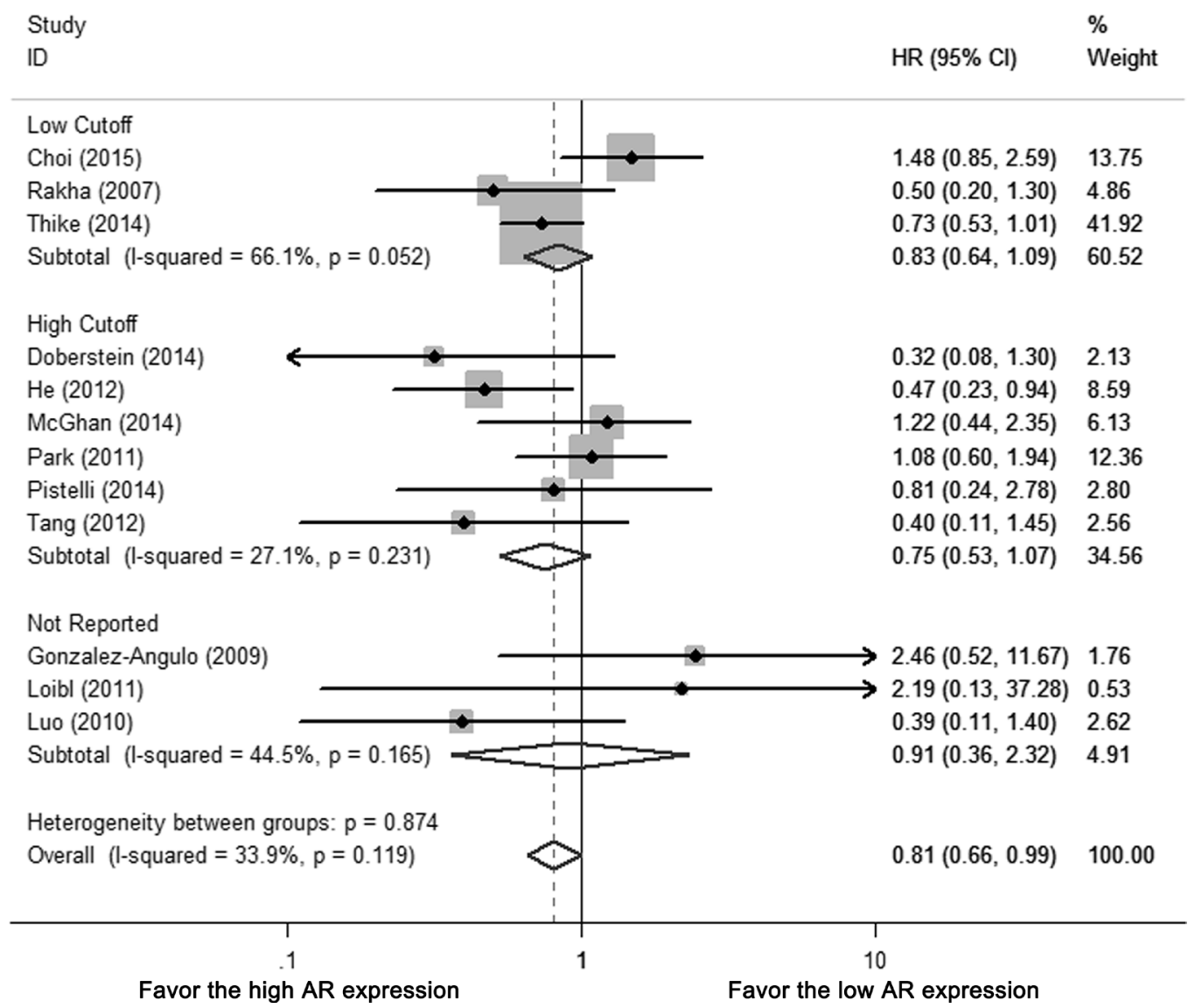

Figure 3: Subgroup analysis of DFS according to different AR cutoffs: low cutoffs (0 or 1\%) vs. high cutoffs $(10 \%)$. Size of square indicates relative contribution of each study. Solid horizontal line represents $95 \% \mathrm{CI}$ of each study. Diamond indicates pooled HR value. 
significant publication bias (DFS $p=0.537$, OS $p=$ 0.945).

\section{DISCUSSION}

As a novel therapeutic target, AR was widely investigated in many pre-clinical and clinical studies for TNBC $[17,19,26]$. However, no consensus for its correlation with TNBC prognosis has been reached to date. Hence, we conducted this meta-analysis including 13 studies and 2826 patients to evaluate AR prognostic value in TNBC. Our study revealed that AR+ TNBC was associated with lower risk of disease recurrence. To the best of our knowledge, this is the first meta-analysis on the correlation of AR expression with TNBC prognosis.

Meta-analyses were conducted to study impacts of AR on DFS and OS for all breast cancer subtypes and drew contradictory results for OS [12] [27]. Study by Qu et al. found that $\mathrm{AR}+$ was beneficial to DFS in TNBC subgroup (HR 0.40, 95\% CI 0.23-0.69), but not for OS (HR 0.90, 95\% CI 0.61-1.32) [12]. Kim et al. suggested that AR expression benefited both DFS and OS (OR, $0.44,95 \%$ CI, 0.26-0.75; OR, 0.26, 95\% CI, 0.12-0.55, respectively) [27]. Since a limited number of studies were included in the two meta-analyses (total four retrospective studies) $[14,16,23,24]$, we conducted this meta-analysis with 13 studies and 2826 patients to provide a more reliable result. In agreement with the study by $\mathrm{Qu}$ et al., AR positivity showed no effect on OS, but lowered recurrence risk in TNBC.

Several studies revealed the antagonizing effect of AR against ER signaling depended on the relative levels of these two steroids receptors. They competed for coregulatory molecules, resulting in opposite effects on cancer cell proliferation [28]. Without functional ER, AR may be the primary driver of downstream signaling and facilitate cancer progression [29, 30]. It implied that different $\mathrm{AR}$ and ER cutoffs could be potential confounding factors and sources of heterogeneity. Hence, we conducted subgroup analysis on AR/ER cutoff values, and proved they had no significant influence on final results. This was consistent with the meta-analysis by Vera-Badillo et al. which demonstrated AR expression incurred better prognosis irrespective of ER co-expression [11]. With ER and AR expression less than $10 \%$, the mutual influence of ER versus AR could be negligible, therefore a suitable model to investigate $\mathrm{AR}$ without potential ER influence could be TNBC with ER $<10 \%$.

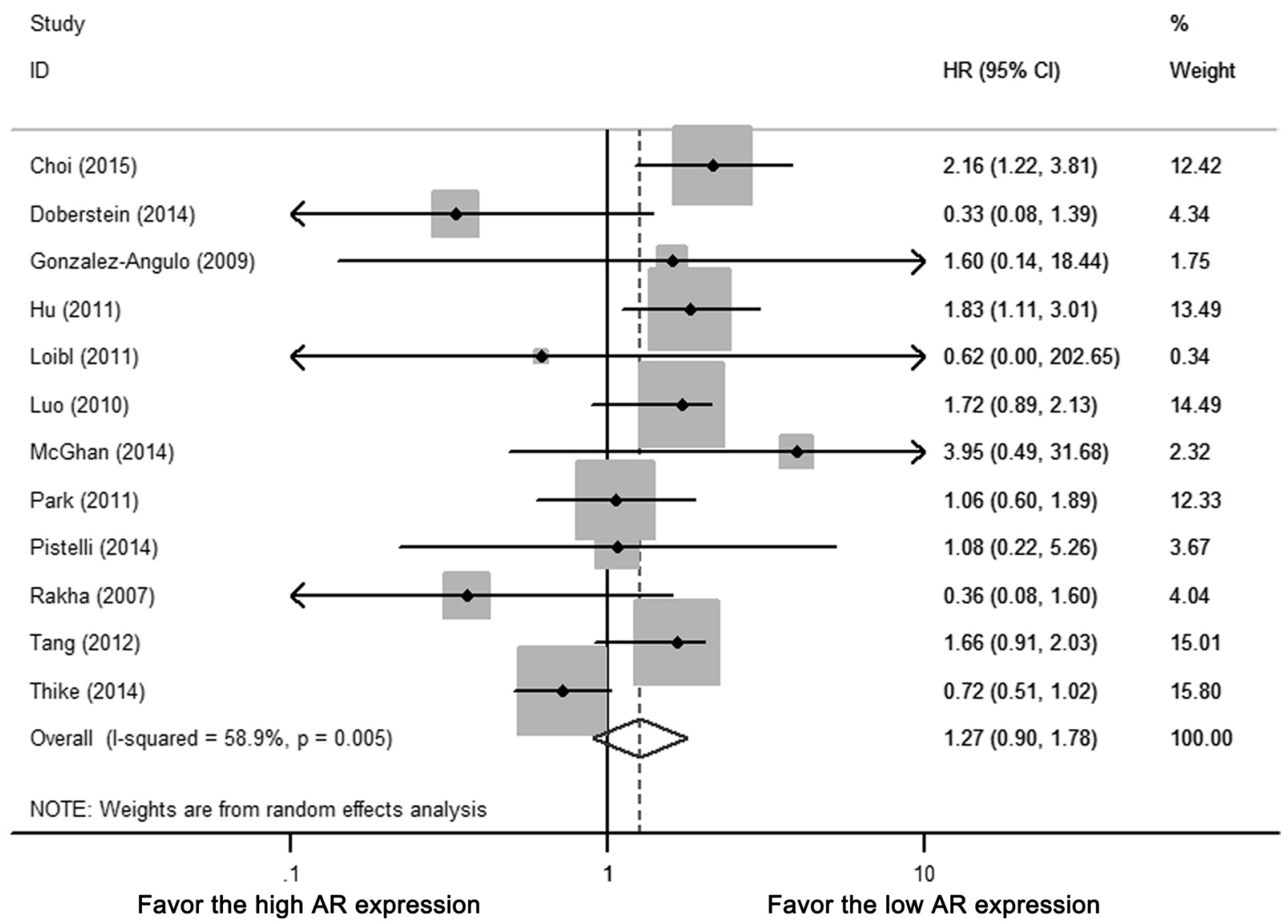

Figure 4: Forest plot of HR for OS. Square indicate point estimate of each study. Size of square indicates relative contribution of each study. Solid horizontal line represents $95 \%$ CI of each study. Diamond indicates pooled HR value. 


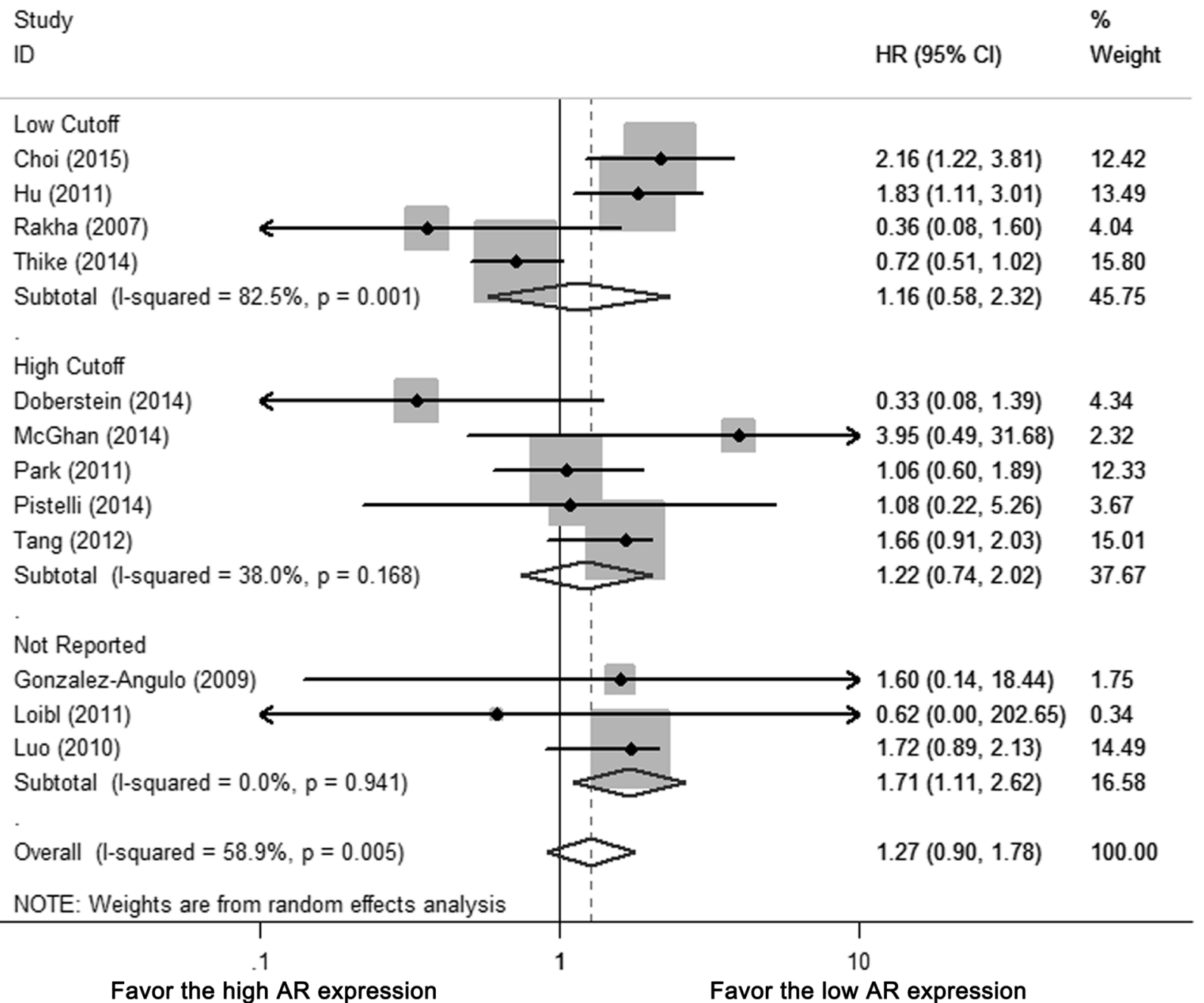

Figure 5: Subgroup analysis of OS according to different AR cutoffs: low cutoffs (0 or $1 \%)$ vs. high cutoffs (5 or $10 \%)$. Size of square indicates relative contribution of each study. Solid horizontal line represents $95 \% \mathrm{CI}$ of each study. Diamond indicates pooled HR value.
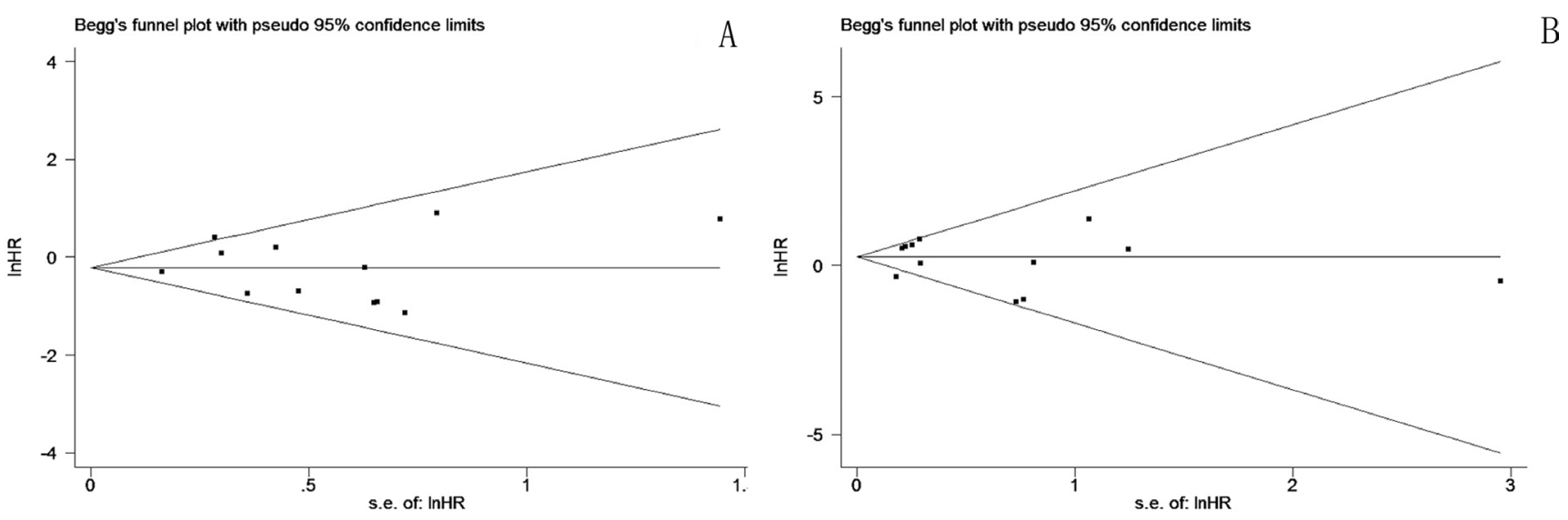

Figure 6: Funnel plot for potential publication bias of DFS A. and OS B. 
Subgroup analyses showed remarkable decrease in the heterogeneity of OS in subgroups of whole-cohort TNBC patients and high AR/ER cutoffs (Supplementary Table S3), suggesting "study population" and "AR/ER cutoff values" as sources of heterogeneity. In agreement with overall result, all subgroups with different AR/ER cutoffs revealed that AR had no significant impact on TNBC OS, which provided additional evidence to AR prognostic value on OS. Moreover, the pooled results were further strengthened by data from subgroup using multivariate analysis, since it provided more reliable data than uni-variate analysis [31].

Our studies had several limitations. First, it based on population data other than individual patient data, and restrained our ability to conduct analyses for LN metastases and other covariates. Second, all the studies were retrospective. It could potentially increase certain bias, such as selection bias. Third, we were unable to identify correlation between AR and molecular intrinsic subtypes of TNBC, especially for LAR subtype which may be helpful to clarify AR prognostic value.

In conclusion, although variability and heterogeneity existed among included studies, AR expression was associated with lower risk of disease recurrence. Since AR had a relatively high prevalence in TNBC, evaluating AR status could provide additional information on prognosis and AR-targeting therapy could be another option for chemotherapy resistant TNBC in both neoadjuvant and metastatic settings. Future clinical trials based on different molecular subtypes of TNBC are warranted to further clarify its prognostic value and efficacy of AR-targeting therapy.

\section{MATERIALS AND METHODS}

\section{Data sources and search strategy}

We searched the following databases for relevant studies: PubMed (from 1946 to July, 2015), Embase (host: Ovid, from 1947 to July, 2015) and Cochrane Central Register of Controlled Trials (CENTRAL, from 2000 to July, 2015). The following medical subject headings, Embase Emtree terms and keywords were used: 'Breast Neoplasms', 'Triple Negative Breast Neoplasms', 'Breast Cancer', 'Triple Negative Breast Cancer', and 'Androgen Receptor'. There was no limitation on languages or regions of publications. Reference lists of all the relevant articles were manually screened to ensure the sensitivity of the literature search.

\section{Selection criteria and quality assessment}

To be eligible, studies had to meet the following inclusion criteria: TNBC patients, or studies that provided data on TNBC as a subgroup; assessment of
AR expression in primary breast cancer tissue; available data of OS or DFS on patient subgroups with different AR level. Exclusion criteria included: metastatic disease; review, meta-analysis, editorial, letter or conference abstract. Two independent reviewers (C.J. Wang and B. Pan) evaluated eligibility of studies according to the above criteria. Full text of the potentially relevant studies were obtained and reviewed for inclusion by the same two reviewers. Disagreement was resolved by consensus (C.J. Wang, B. Pan, Q. Sun). Inter-reviewer agreement was assessed by Kappa Statistics according to Higgins et al. [32]

The quality of the included studies was assessed according to the STROBE checklist for Cohort Studies [33]. Each item in the STROBE Checklist was scored using an ordinal scale (1-5, with $1=$ Worst, $5=$ Best) by two independent reviewers (C.J. Wang and B. Pan). The final quality scores were the average of scores generated by each reviewer and expressed as percentages, ranging $0-100 \%$, where higher values indicated a better methodological quality.

\section{Data extraction}

Data were collected using a predesigned data extraction form by two reviewers (C.J Wang and B. Pan). Characteristics of included studies were extracted for stratified analyses and meta-regression. Survival data (HR with $\mathrm{CI}$ and $p$-value) were extracted from tables or text of included studies, or estimated from Kaplan-Meier curves where applicable [34].

\section{Statistical analysis}

Statistical variables such as HR and corresponding CI were directly taken and used for the meta-analysis. Other data were presented as means and proportions, differences between groups were tested with Pearson Chi-square test. The HR of OS and DFS was chosen as the primary analytical endpoint. Fixed effects or random effects models were used based on whether significant heterogeneity existed between studies.

Publication bias was assessed by Begg's test and symmetry of funnel plot. Statistical heterogeneity was assessed by Cochrane's Q and I-square statistics. Cochrane's $\mathrm{Q}$ test with $p<0.05$ or I-square $>50 \%$ indicated significant heterogeneity among included studies. To investigate potential heterogeneity across studies, subgroup analyses were performed according to methods described by Deeks et al. [31]. Metaregression was conducted for all potential confounding factors. All the statistical tests were two-sided, and statistical significance was defined as $p<0.05$. Statistical analyses were conducted by STATA version 12.0 (Stata Corporation, College Station, TX, USA). 


\section{CONFLICTS OF INTEREST}

The authors declare that they have no conflicts of interest concerning this article.

\section{GRANT SUPPORT}

Dr. Qiang Sun received financial support by Key Projects in the National Science \& Technology Pillar Program during the Twelfth Five-year Plan Period (2014BAI08B00). Dr. Changjun Wang and Dr. Bo Pan received financial support by PUMCH-UCSF Joint Funding Program (PUMCH-UCSF RT201504).

\section{REFERENCES}

1. Reis-Filho JS, Tutt AN. Triple negative tumours: a critical review. Histopathology. 2008; 52:108-118.

2. Dent R, Trudeau M, Pritchard KI, Hanna WM, Kahn HK, Sawka CA, Lickley LA, Rawlinson E, Sun P, Narod SA. Triple-negative breast cancer: clinical features and patterns of recurrence. Clin Cancer Res. 2007; 13:4429-4434.

3. Bauer KR, Brown M, Cress RD, Parise CA, Caggiano V. Descriptive analysis of estrogen receptor (ER)-negative, progesterone receptor (PR)-negative, and HER2-negative invasive breast cancer, the so-called triple-negative phenotype: a population-based study from the California cancer Registry. Cancer. 2007; 109:1721-1728.

4. Lehmann BD, Bauer JA, Chen X, Sanders ME, Chakravarthy AB, Shyr Y, Pietenpol JA. Identification of human triple-negative breast cancer subtypes and. The Journal of Clinical Investigation. 2011; 121:2750-2767.

5. Farmer $\mathrm{P}$, Bonnefoi H, Becette V, Tubiana-Hulin M, Fumoleau P, Larsimont D, Macgrogan G, Bergh J, Cameron D, Goldstein D, Duss S, Nicoulaz AL, Brisken C, et al. Identification of molecular apocrine breast tumours by microarray analysis. Oncogene. 2005; 24:4660-4671.

6. McNamara KM, Yoda T, Takagi K, Miki Y, Suzuki T, Sasano H. Androgen receptor in triple negative breast cancer. The Journal of steroid biochemistry and molecular biology. 2013; 133:66-76.

7. Birrell SN, Bentel JM, Hickey TE, Ricciardelli C, Weger MA, Horsfall DJ, Tilley WD. Androgens induce divergent proliferative responses in human breast cancer cell lines. The Journal of steroid biochemistry and molecular biology. 1995; 52:459-467.

8. Cops EJ, Bianco-Miotto T, Moore NL, Clarke CL, Birrell SN, Butler LM, Tilley WD. Antiproliferative actions of the synthetic androgen, mibolerone, in breast cancer cells are mediated by both androgen and progesterone receptors. The Journal of steroid biochemistry and molecular biology. 2008; 110:236-243.

9. Poulin R, Baker D, Labrie F. Androgens inhibit basal and estrogen-induced cell proliferation in the ZR-75-1 human breast cancer cell line. Breast cancer research and treatment. 1988; 12:213-225.

10. Doane AS, Danso M, Lal P, Donaton M, Zhang L, Hudis C, Gerald WL. An estrogen receptor-negative breast cancer subset characterized by a hormonally regulated transcriptional program and response to androgen. Oncogene. 2006; 25:3994-4008.

11. Vera-Badillo FE, Templeton AJ, de Gouveia P, Diaz-Padilla I, Bedard PL, Al-Mubarak M, Seruga B, Tannock IF, Ocana A, Amir E. Androgen receptor expression and outcomes in early breast cancer: a systematic review and meta-analysis. Journal of the National Cancer Institute. 2014; 106:djt319.

12. $\mathrm{Qu} \mathrm{Q}$, Mao Y, Fei XC, Shen KW. The impact of androgen receptor expression on breast cancer survival: a retrospective study and meta-analysis. PloS one. 2013; 8:e82650.

13. Park S, Koo JS, Kim MS, Park HS, Lee JS, Lee JS, Kim SI, Park BW, Lee KS. Androgen receptor expression is significantly associated with better outcomes in estrogen receptor-positive breast cancers. [Article]. Annals of Oncology August. 2011; 22:1755-1762.

14. Tang D, Xu S, Zhang Q, Zhao W. The expression and clinical significance of the androgen receptor and E-cadherin in triple-negative breast cancer. Medical oncology (Northwood, London, England). 2011; 29:526-533.

15. Loibl S, Muller BM, von Minckwitz G, Schwabe M, Roller M, Darb-Esfahani S, Ataseven B, du Bois A, FisslerEckhoff A, Gerber B, Kulmer U, Alles J-U, Mehta K, et al. Androgen receptor expression in primary breast cancer and its predictive and prognostic value in patients treated with neoadjuvant chemotherapy. [Miscellaneous]. Breast Cancer Research \& Treatment November. 2011; 130:477-487.

16. Luo X, Shi YX, Li ZM, Jiang WQ. Expression and clinical significance of androgen receptor in triple negative breast cancer. Chinese journal of cancer. 2010; 29:585-590.

17. Choi JE, Kang SH, Lee SJ, Bae YK. Androgen receptor expression predicts decreased survival in early stage triplenegative breast cancer. Annals of surgical oncology. 2014; 22:82-89.

18. Thike AA, Yong-Zheng Chong L, Cheok PY, Li HH, WaiCheong Yip G, Huat Bay B, Tse GM, Iqbal J, Tan PH. Loss of androgen receptor expression predicts early recurrence in triple-negative and basal-like breast cancer. Mod Pathol. 2013; 27:352-360.

19. Rakha EA, El-Sayed ME, Green AR, Lee AH, Robertson JF, Ellis IO. Prognostic markers in triple-negative breast cancer. Cancer. 2006; 109:25-32.

20. Pistelli M, Caramanti M, Biscotti T, Santinelli A, Pagliacci A, De Lisa M, Ballatore Z, Ridolfi F, Maccaroni E, Bracci R, Berardi R, Battelli N, Cascinu S. Androgen receptor expression in early triple-negative breast cancer: clinical significance and prognostic associations. Cancers. 2014; 6:1351-1362. 
21. McGhan LJ, McCullough AE, Protheroe CA, Dueck AC, Lee JJ, Nunez-Nateras R, Castle EP, Gray RJ, Wasif N, Goetz MP, Hawse JR, Henry TJ, Barrett MT, et al. Androgen receptor-positive triple negative breast cancer: a unique breast cancer subtype. Annals of surgical oncology. 2013; 21:361-367.

22. $\mathrm{Hu} \mathrm{R}$, Dawood S, Holmes MD, Collins LC, Schnitt SJ, Cole K, Marotti JD, Hankinson SE, Colditz GA, Tamimi RM. Androgen receptor expression and breast cancer survival in postmenopausal women. Clin Cancer Res. 2011; 17:1867-1874.

23. He J, Peng R, Yuan Z, Wang S, Peng J, Lin G, Jiang X, Qin T. Prognostic value of androgen receptor expression in operable triple-negative breast cancer: a retrospective analysis based on a tissue microarray. Medical oncology (Northwood, London, England). 2011; 29:406-410.

24. Gonzalez-Angulo AM, Stemke-Hale K, Palla SL, Carey M, Agarwal R, Meric-Berstam F, Traina TA, Hudis C, Hortobagyi GN, Gerald WL, Mills GB, Hennessy BT. Androgen receptor levels and association with PIK3CA mutations and prognosis in breast cancer. Cancer Res. 2009; 15:2472-2478.

25. Doberstein K, Milde-Langosch K, Bretz NP, Schirmer U, Harari A, Witzel I, Ben-Arie A, Hubalek M, MullerHolzner E, Reinold S, Zeimet AG, Altevogt P, Fogel M. L1CAM is expressed in triple-negative breast cancers and is inversely correlated with androgen receptor. BMC Cancer. 2014; 14:958.

26. Gucalp A, Tolaney S, Isakoff SJ, Ingle JN, Liu MC, Carey LA, Blackwell K, Rugo H, Nabell L, Forero A, Stearns V, Doane AS, Danso M, et al. Phase II trial of bicalutamide in patients with androgen receptor-positive, estrogen receptor-negative metastatic Breast Cancer. Cancer Res. 2013; 19:5505-5512.

27. Kim Y, Jae E, Yoon M. Influence of Androgen Receptor Expression on the Survival Outcomes in Breast Cancer: A Meta-Analysis. J Breast Cancer. 2015; 18:134-142.

28. Peters AA, Ingman WV, Tilley WD, Butler LM. Differential effects of exogenous androgen and an androgen receptor antagonist in the peri- and postpubertal murine mammary gland. Endocrinology. 2011; 152:3728-3737.

29. De Amicis F, Thirugnansampanthan J, Cui Y, Selever J, Beyer A, Parra I, Weigel NL, Herynk MH, Tsimelzon A, Lewis MT, Chamness GC, Hilsenbeck SG, Ando S, et al. Androgen receptor overexpression induces tamoxifen resistance in human breast cancer cells. Breast cancer research and treatment. 2010; 121:1-11.

30. Hickey TE, Robinson JL, Carroll JS, Tilley WD. Minireview: The androgen receptor in breast tissues: growth inhibitor, tumor suppressor, oncogene? Molecular endocrinology. 2012; 26:1252-1267.

31. Deeks JJ HJ, Altman DG (editors). Chapter9: Analysing data and undertaking meta-analyses. In: Higgins JPT, Green $\mathrm{S}$ (editors). Cochrane Handbook for Systematic Reviews of Interventions Chichester (UK) John Wiley \& Sons. 2008.

32. Higgins JPT DJe. Chapter 7: Selecting studies and collecting data. In: Higgins JPT, Green S (editors), Cochrane Handbook for Systematic Reviews of Interventions Chichester (UK): John Wiley \& Sons. 2008.

33. STROBE checklist for cohort studies version 4 . http://strobestatement.org/index.php?id=available-checklists 2007.

34. Tierney JF, Stewart LA, Ghersi D, Burdett S, Sydes MR. Practical methods for incorporating summary time-to-event data into meta-analysis. Trials. 2007; 8:16. 